\title{
İşbirlikli Öğrenme ve Modellerin Fiziksel ve Kimyasal Değişim Olaylarının Tanecikli Yapıda Anlaşılmasına Etkisi
}

\author{
DOI: $10.26466 /$ opus.534640 \\ *
}

\section{Oylum Çavdar $^{*}$ - Seda Okumuş ${ }^{* *}-$ Mustafa Alyar ${ }^{* * *}-K^{*}$ emal Doymuş ${ }^{* * *}$}

* Dr. Öğr. Üyesi, Muş Alparslan Üniversitesi, Eğitim Fakültesi, Merkez/Muş/ Türkiye

E-Posta: o.cavdar@alparslan.edu.tr

ORCID: 0000-0001-8405-0969

${ }^{*}$ Dr. Öğr. Üyesi,Atatürk Üniversitesi, Kazım Karabekir Eğitim Fakültesi,Yakutiye,Erzrum,Türkiye

E-Posta: seda.okumus@atauni.edu.tr

ORCID: $\quad 0000-0001-6271-8278$

${ }^{* * *}$ Ar. Gör. Dr., Çukurova Üniversitesi, Eğitim Fakültesi, Sarıçam /Adana/Türkiye

E-Posta: alyarm@cu.edu.tr ORCID: 0000-0003-3774-353X

${ }^{* * * * *}$ Prof. Dr., Atatürk Üniversitesi, Kazım Karabekir Eğitim Fakültesi, Yakutiye /Erzurum/Türkiye

E-Posta: kdoymus@atauni.edu.tr

ORCID: $\quad \underline{0000-0002-0578-5623}$

\section{Öz}

Bu araştırmada fiziksel ve kimyasal değişim olaylarının tanecikli boyutta anlaşılmasına işbirlikli öğrenme ve modellerin etkisi araştırılmıştır. Araştırma, ön -son test içeren kontrol gruplu yartdeneysel desendedir. Araştırma grubunu fen bilgisi öğretmenliğinde öğrenim gören 71 öğretmen adayı oluşturmaktadır. Araştırma, İşbirlikli Öğrenme Grubu (İÖG, n=24) ve İşbirlikli- Model Grubu (İMG, $n=24)$ olarak iki deney grubu ve bir Kontrol Grubu (KG, n=23) ile yürütülmüştür. Açık uçlu üç çizim sorusundan oluşan Fiziksel ve Kimyasal Değişim Testi (FKDT) veri toplama aracı olarak kullanılmıştır. FKDT verilerinin analizi için Kruskall-Wallis ve Mann- Whitney U testi kullanılmış, kavramsal anlamaları belirlemek amacıyla ise tanımlayıcı istatistikler yapılmıştır. Ön testte gruplar arasında anlamlı bir fark gözlenmezken, son testte anlamlı bir fark görülmüştür. Ayrıca, bazı öğretmen adaylarının maddeyi tanecikli yapıdan ziyade bütünsel olarak düşündükleri, katı haldeki maddelerin tanecikli çiziminde problem yaşadıkları, fiziksel ve kimyasal değişim kavramlarında çeşitli yanılgılarının olduğu belirlenmiştir.

Anahtar Kelimeler: Fiziksel ve kimyasal değiş̧im, maddenin tanecikli yapısı, işbirlikli öğrenme, model. 


\title{
Effect of Cooperative Learning and Models on the Understanding of Particulate Structure of Physical and Chemical Changes
}

\begin{abstract}
In this study, the effect of models and cooperative learning on particulate level of physical and chemical changes was investigated. Quasi-experimental method pre-and post-test was used. The sample was consisted 71 prospective science teachers. Three research groups (CLG: cooperative learning group, $n=24$; CLMG: cooperative-model group, $n=24$; and control group $(C G, n=23)$ were studied. In order to collect data, the Physical and Chemical Changing Test (PCCT) consisting of three open-ended drawing questions was applied as pre- and posttest. For the analysis of data obtained from the PCCT, the Kruskal-Wallis and Mann-Whitney $U$ tests were used and descriptive statistics were used to determine the conceptual understanding. In the pre-test there was not a significant difference among groups. In the post-test, there was a significant difference among research groups. In addition, some prospective science teachers thought the matter as a whole rather than a particulate structure, had a problem in the particulate drawing of solid materials, and had various misconceptions in the concepts of physical and chemical change.
\end{abstract}

Keywords: Physical and chemical changes, the particulate nature of matter, cooperative learning, model. 


\section{Giriş}

Fiziksel ve kimyasal değişim konusu kimyaya temel teşkil etmesine rağmen öğrenciler tarafından tam olarak anlaşılamayan bir konudur (Okumuş ve Doymuş, 2017). Fiziksel değişim ile ilgili olarak ülkemiz ve dünya literatüründe şu şekilde yanılgılar tespit edilmiştir: "fiziksel ve kimyasal değişim birbirinin tersi olaylardır" (Meşeci, Tekin ve Karamustafaoğlu, 2013), "düşük sıcakliklarda buharlaşma olmaz" (Karslı ve Ayas, 2013), "hal değişimi kimyasal değişimdir" (Çayan ve Karsl1, 2015) "hal değgişimi sırasında maddenin kütlesi değişir" (Lee, Eichinger, Anderson, Berkheimer ve Blakeslee, 1993) ve "maddenin dış görünüşünün değişimi fiziksel bir değişimdir" (Ayvacı ve Şenel Çoruhlu, 2009). Kimyasal değişimle ilgili ise, maddedeki değişmelerde tanecik sayısının ve kütlenin korunması gerektiğinin önemsenmemesi" (Meşeci vd., 2013), "kimyasal değişimlerin geri dönüşümsü̈z olduğu" (Eilks, Moellering ve Valanides, 2007), "çözünme olayının kimyasal bir değişim olduğu" (Smith ve Nakleh, 2011), "kimyasal değişimlerde taneciklerin yapısının değişmeyeceğgi" (Ayvacı ve Çoruhlu, 2009), ve "sadece fiziksel değişimde maddenin dış görünüşünün değiştiği" (Kıngır ve Geban, 2014) şeklinde birçok kavram yanılgısı bulunmaktadır. Öğrencilerin büyük bir kısmı fiziksel değişim ve kimyasal değişimi birbirinden ayırt etmede zorlanmaktadır (Okumuş ve Doymuş, 2017). Bu problemin başlıca nedeninin kimyasal değişimin tanecik boyutunda düşünülememesi ve buna bağlı olarak kimyasal değişimin gözlenebilen birtakım özelliklerle (renk değişimi, gaz çıkışı gibi) makro düzeyde açıklanması olduğu ifade edilmektedir (Demircioğlu, Demircioğlu, Ayas ve Kongur, 2012).

Etkili bir kimya öğretimi için mikro, makro ve sembolik boyutlar üzerinde durulmuştur. Mikro boyut gözle görülemeyecek olayları içerirken, makro boyut günlük hayatta karşılaşılabilecek, gözle görülebilen olayları ve durumları içerir. Sembolik boyut ise kimyasal durumların sembollerle ve formüllerle ifade edilmesidir (Jaber ve Boujaoude, 2012; Johnstone, 1991; Raviolo, 2001). Kimyanın tam olarak anlaşılabilmesi için bu üç boyutun mutlaka ilişkilendirilmesi gerekmektedir (Jaber ve Boujaoude, 2012; Johnstone, 1991; Talanquer, 2011). Bu boyutların kullanımı ile ilgili olarak yürütülen araştırmalarda öğrencilerin makro boyutu rahatlıkla anlayabildikleri, makro boyutu sembolik boyutla ilişkilendirebildikleri ancak mikro boyuttaki olayları veya durumları makroskobik seviyede 
açıklama eğiliminde oldukları belirlenmiştir (Adadan, 2014; Jaber ve Boujaoude, 2012). Üç boyutun doğru ilişkilendirilememesi sonucunda kavram yanılgıları ortaya çıkmaktadır (Karaçöp ve Doymuş, 2013). Öğrencilerin en fazla problem yaşadıkları boyut olan mikro boyutun tam ve doğru olarak anlaşılması maddenin tanecikli yapısının da anlaşılmasını sağlayacaktır (Papageorgiou, Stamovlasis ve Johnson, 2010). Mikro boyut gözle görülemeyen soyut olay ve durumları içerdiği için somutlaştırıcı materyaller veya etkinlikler kullanılarak öğretim sağlanmalıdır (Krell, Reinisch ve Krüger, 2015; Wang, Chi, Hu ve Chen, 2014). Somutlaştırıcı materyaller dendiğinde ilk akla gelen modellerdir (Okumuş ve Doymuş, 2018). Modellerin kimya eğitiminde kullanılması, öğrencilerin kimya kavramlarını doğru olarak anlamalarını sağlar ve konunun akılda kalıcılığını arttırır (Çavdar ve Doymuş, 2016b, 2018; Krell vd., 2015; Okumuş ve Doymuş, 2018; Wang vd., 2014). Modeller öğrencilerin mikro boyutu zihinlerinde daha iyi canlandırabilmelerini sağlar (Çavdar ve Doymuş, 2016b, 2018; Oliva, Aragon ve Cuesta, 2015; Wei, Liu ve Jia, 2013).

Öğrencilerin fiziksel ve kimyasal değişimlerle ilgili kavram yanılgılarına sahip olmalarının bir diğer önemli nedeninin de konuların soyut yapısı (Papageorgiou vd., 2010) olduğu düşünülmektedir. Bu konuların öğretiminde kullanılan yöntem ve materyallerin yeterince somutlaştırma içermemesi, öğrencilerin soyut yapıları anlamlandırmalarına yardımcı olamamaktadır (Jaber ve Boujaoude, 2012). Öğrencilere fiziksel ve kimyasal değişim konusunun kavratılmasında öğrenciyi merkeze alan ve sürece bizzat katılmasını sağlayan yöntem ve tekniklerin kullanılması gerekmektedir. Çünkü oldukça soyut olan kavramların öğrenilmesinde öğrencinin bizzat sürece katılması ve konu ile ilgili görüşlerini arkadaşları ile tartışarak anlamadığı kısımları anlamlandırması kavramları doğru yapılandırmasına yardımcı olacaktır. Aktif öğrenmeyi sağlayan birçok yöntem ve teknik bulunmaktadır. İşbirlikli öğrenme bunlardan biridir. İşbirlikli öğrenme, öğrencilerin hem kendilerinin hem de grup arkadaşlarının öğrenmelerinden sorumlu oldukları, sosyal ve akademik yönden öğrencilerin geliştirilmesinin amaçlandığı bir aktif öğrenme yöntemidir (Çavdar ve Doymuş, 2016a; Okumuş ve Doymuş, 2018). İşbirlikli öğrenme, öğrenme sürecinde hem öğrencinin bizzat çalışmasını hem de grup arkadaşları ile etkileşim içerisinde olmasını gerektirdiği için öğrencilerin 
konuyu anlamalarında etkili bir yol olacağı düşünülmektedir. Ayrıca işbirlikli öğrenmenin doğası gereği öğrenciler grup çalışmaları yapacak ve birbirlerinin öğrenmelerine yardımcı olacaklardır (Doymuş, Karaçöp ve Şimşek, 2010). Diğer taraftan işbirlikli öğrenmenin kavramsal anlama üzerine de olumlu etki ettiği belirlenmiştir (Belge Can ve Boz, 2016; Çavdar ve Doymuş, 2016b, 2018; Eymur ve Geban, 2017; Okumuş ve Doymuş, 2018).

İşbirlikli öğrenmenin Jigsaw, Birlikte Öğrenme (BÖ), Öğrenci Takımları Başarı Bölümleri (ÖTBB), Grup Araştırması (GA), Okuma Yazma Uygulama (OYU), Takım Oyun Turnuva (TOT) gibi birçok yöntem ve tekniği mevcuttur (Güngör ve Özkan, 2011). Bunlardan ÖTBB yöntemi, öğrenme sürecinde hem öğretmenin konuyu anlatmasına hem de öğrencilerin grup halinde çalışmalarına imkan tanıdığı için öğrenci başarısını arttırmada çok kullanışlı bir yöntemdir (Okumuş, Çavdar, Alyar ve Doymuş, 2017). Nitekim yapılan çalışmalarda, ÖTBB'nin diğer işbirlikli yöntem ve tekniklerinden daha başarılı olduğu tespit edilmiştir (Aksoy ve Gürbüz, 2012; Koç, 2014).

Fiziksel ve kimyasal değişimlerle ilgili yürütülen araştırmalarda öğrencilerin kavram yanılgılarının belirlenmesi (Kıngır ve Geban, 2014) ve kavramsal değişim sağlanması (Chang, Quintana ve Krajcik, 2010) amaçlanmıştır. Buna göre çeşitli yöntem ve teknikler işe koşulmuş, kavramsal anlamalar geliştirilmeye çalışılmıştır. Bu araştırmada da aktif öğrenme yöntemlerinden işbirlikli öğrenme ve soyut durumları somutlaştırıcı görsel materyallerden olan modellerden faydalanılacaktır.

Kimyanın öğretimi üzerine yapılan birçok araştırmada ortaokul, lise ve üniversite düzeyindeki öğrencilerle çalışılmıştır. Öğrencilerin ortaokul seviyesinde yanlış öğrendikleri kavramları daha sonra doğrusu ile değiştirmede zorlandıkları ifade edilmektedir (Çavdar ve Doymuş, 2016b, 2018; Çavdar, Okumuş ve Doymuş, 2016; Okumuş ve Doymuş, 2018). Bu bakımdan ortaokul seviyesinde kavramların doğru öğrenilmesi önem arz etmektedir. Ortaokul öğrencilerinin kimya kavramlarını yanlış öğrenmeleri fen bilimleri öğretmenlerinden kaynaklanabilir. Bu bakımdan fen bilimleri öğretmeni yetiştirme aşamasında mutlaka öğretmen adaylarına kavramların doğruları öğretilmelidir. Bu nedenle bu araştırmada kimyanın temel konularından olan fiziksel ve kimyasal değişimler 
konusunda fen bilgisi öğretmen adaylarının yanılgıları tespit edilecek ve giderilmeye çalışılacaktır.

$\mathrm{Bu}$ araştırmada fen bilgisi öğretmen adaylarının fiziksel ve kimyasal değişim olaylarını tanecikli yapıda anlamaları üzerine ÖTBB yöntemi ve modellerin etkisinin belirlenmesi amaçlanmıştır. Buna göre araştırmanın problem cümlesi: "Fen bilgisi öğretmen adaylarının fiziksel ve kimyasal değişim olaylarını tanecikli yapıda anlamaları üzerinde ÖTBB yöntemi ve modellerin etkisi var mıdır?" şeklindedir. Alt problemler:

1. Fiziksel ve kimyasal değişimler konusuyla ilgili gruplar arasında uygulamadan önce ve sonra anlamlı bir fark var mıdır?

2. Fiziksel ve kimyasal değişimler konusuyla ilgili fen bilgisi öğretmen adaylarının uygulamadan önce ve sonra sahip oldukları yanılg1lar nelerdir?

\section{Yöntem}

Çalışmanın bu bölümünde; araştırma deseninden, çalışma grubundan, veri toplama aracindan, verilerin analizinden ve uygulama sürecinden bahsedilmektedir.

\section{Araştırmanın Deseni}

Araştırma müdahaleli desenlerden yarı deneysel desendedir. Yarı deneysel desende, tam deneysel desende olduğu gibi örneklem seçimi tamamen tesadüfi değildir (Büyüköztürk, Kılıç Çakmak, Akgün, Karadeniz ve Demirel, 2012). Çalışma grupları genellikle önceden bellidir (örneğin okullardaki şubelerin belli olması gibi) ve gruplarda bulunan bireylere müdahale edilememekte, bunun yerine hangi grubun deney grubu hangi grubun kontrol grubu olacağı araştırmacılar tarafından tesadüfi olarak atanmaktadır (McMillan ve Schumacher, 2010). Bu araştırma kontrol gruplu ön- son uygulamalı yarı-deneysel desen ile yürütülmüştür. 


\section{Çalışma Grubu}

Bu araştırmada 2016-2017 eğitim- öğretim yılı güz yarıyılında Atatürk Üniversitesi fen bilgisi öğretmenliği birinci sınıfında öğrenim gören ve Genel Kimya Laboratuvarı- I dersine devam eden 71 öğretmen adayı (58 kadın, 13 erkek) ile çalışılmıştır. Çalışmada üç grup belirlenmiştir: İşbirlikli Öğrenme Grubu (IOÖG, n=24; 19 kadın, 5 erkek); İşbirlikli Model Grubu (İMG, n=24; 23 kadın, 1 erkek) ve Kontrol Grubu (KG, n= 23; 16 kadın, 7 erkek). Fen bilgisi öğretmenliği programında öğrenim gören erkek öğretmen adaylarının sayısı azdır. Öğretmen adayları gruplara daha önceden atandığı için grupların üyelerine müdahale edilememiş, sadece hangi grubun deney hangi grubun kontrol grubu olacağı rastgele seçilmiştir. Bu nedenle cinsiyet bakımından heterojenlik tam sağlanamamıştır. Öğretmen adaylarının tümü lise öğrenimi boyunca kimya dersi almıştır, bu nedenle ön koşul bilgilerin tüm öğretmen adaylarında benzer şekilde olduğu varsayılmaktadır. Ayrıca, öğretmen adayları aynı yarıyılda Genel Kimya Laboratuvarı- I dersine paralel olarak Genel Kimya I dersini almışlardır.

\section{Veri Toplama Aracı}

Veri toplama aracı olarak üç açık uçlu çizim sorusundan oluşan Fiziksel ve Kimyasal Değişimler Testi (FKDT) kullanılmıştır. Çizim soruları, sözel ifadelerin görsel olarak açılanmasına olanak tanır ve bireyin zihinsel kavram modellerine erişimi sağlar (Adadan, 2014). Bu bakımdan bu araştırmada, öğretmen adaylarının fiziksel ve kimyasal değişimleri tanecik düzeyinde nasıl algıladıklarının belirlenmesi amacıyla çizim testinden faydalanılmıştır. FKDT'deki birinci soruda öğretmen adaylarından temsili şekli verilen magnezyum şeridin tanecik yapısını çizmeleri istenmiştir. İkinci soruda magnezyum şeritten bölünen küçük bir parçanın taneciklerini çizmeleri istenmiştir. Üçüncü soruda ise öğretmen adaylarından magnezyum şeridin yakıldıktan sonra taneciklerin nasıl olacağını temsili olarak çizmeleri istenmiştir. Testin geçerliği için, FKDT'deki sorular iki fen eğitimcisi tarafından incelenmiştir. Önerilen düzeltmeler yapıldıktan sonra teste son hali verilmiştir. Güvenirlik için ise puanlayıcılar arası tutarlılığa bakılmıştır. Buna göre iki araştırmacı, öğretmen adayla- 
rını çizimlerini cevap anahtarını dikkate alarak ayrı ayrı puanlamış, daha sonra karşılaştırma yapmıştır. Karşılaştırmada her iki puanlamanın büyük oranda aynı olduğu görülmüştür.

\section{Verilerin Analizi}

FKDT'den elde edilen çizimler öncelikle puanlanmıştır. Buna göre; doğru çizim " 10 ", hatalı çizim ve cevap yok " 0 " olarak puanlanmıştır. Daha sonra tüm öğretmen adaylarının ön ve son uygulamada aldıkları puanlar belirlenip SPSS programına aktarılmıştır. Araştırmanın birinci alt problemine cevap aramak için öncelikle verilerin normal dağılımına uygunluğu Shapiro-Wilk testi ile incelenmiştir. Ön ve son testte gruplar arasında anlamlı farklılığın olup olmadığının belirlenmesi amacıyla KruskallWallis ve Mann- Whitney $U$ testi yapılmıştır. Araştırmanın ikinci alt problemine cevap aramak için ise öğretmen adaylarının her bir soru için yaptıkları çizimler ayrıntılı olarak incelenmiş, kavram yanılgıları belirlenmiş ve yüzdeleri hesaplanarak sunulmuştur.

\section{Uygulama Süreci}

Öncelikle fen bilgisi öğretmenliği birinci sınıfında öğrenim gören ve Genel Kimya Laboratuvarı- I dersine devam eden öğretmen adayları üç araştırma grubuna (IÖG, İMG, KG) tesadüfi olarak atanmıştır. Sınıf içi uygulamalardan önce, FKDT ön test olarak tüm gruplara uygulanmıştır. Ardından her grup, kendi öğretim yöntemine göre konuya çalışmıştır.

İÖG'deki öğretmen adayları ÖTBB yöntemine göre işbirlikli çalışma gruplarına ayrılmıştır. Grupların oluşturulmasında FKDT'nin ön uygulamasından alınan puanlara göre ve cinsiyete göre heterojenlik sağlanmıştır. Grup üyelerinin bir süre birlikte çalışması ve birbirlerini tanımaları sağlanmıştır. Ardından araştırmacı Fiziksel ve Kimyasal Değişim konusunu kısa bir şekilde öğretmen adaylarına anlatmıştır. Daha sonra her grup, deney föyünü birlikte okumuş ve konuyu takım arkadaşlarıyla tartışmıştır. Daha sonra her bir grup "fiziksel ve kimyasal değişim" deneyini yapmıştır. Fiziksel ve kimyasal değişim deneyinin ilk bölümünde öğretmen adayları, kendilerine verilen magnezyum şeritleri makasla küçük parçalara bölerek oluşan değişimi gözlemlemişlerdir. İkinci bölümde ise 
öğretmen adayları magnezyum şeritleri ispirto ocağında yakmışlar ve yanma sonucu elde ettikleri ürünü porselen kroze içinde incelemişlerdir.

IMG'de ÖTBB yöntemi modellerle birlikte uygulanmıştır. Buna göre İMG'de İÖG'de yapılan uygulamalara ek olarak, öğretmen adaylarına "fiziksel ve kimyasal değişim" deneyini yaptıktan sonra molekül modelleri seti ve oyun hamurları dağıtılmıştır. Her gruptan, molekül modelleri ve oyun hamurlarını kullanarak fiziksel bir değişim olan suyun buharlaşması ile kimyasal bir değişim olan suyun oluşumu olaylarını tanecik boyutunda modellemeleri istenmiştir.

$K G^{\prime}$ de geleneksel laboratuvar yaklaşımı kullanılmıştır. Öğretmen adayları liste sırasına göre kümelere ayrılmıştır. Kümelerin oluşturulmasinda heterojenliğe dikkat edilmemiştir. Ardından gruplar konuya çalışmış ve deney föyünü okumuşlardır. Burada geleneksel küme çalışması düzeninde çalışmalar yürütülmüştür, öğretmen adaylarının işbirlikli çalışması istenmemiştir. Ardından gruplar "fiziksel ve kimyasal değişim" deneyini yapmıştır. Şekil 1'de öğretmen adaylarının deney çalışmalarından, Şekil 2'de ise İMG'de yürütülen model çalışmalarından örnekler sunulmuştur.

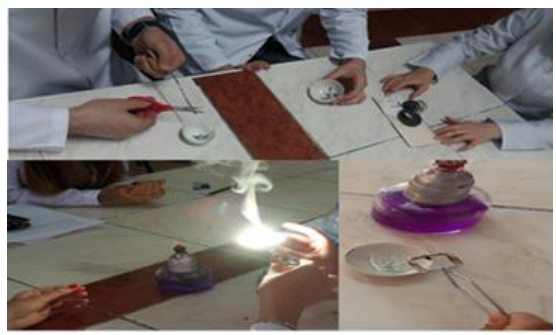

Şekil 1. Fiziksel ve kimyasal değişim deneyi

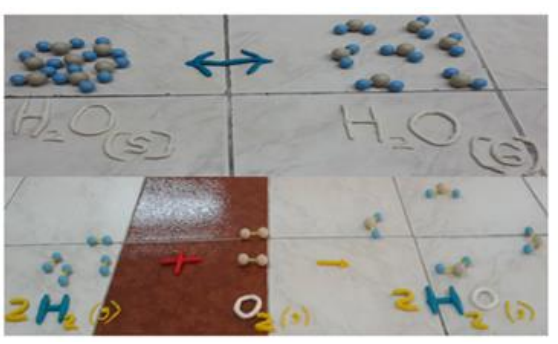

Şekil 2. IMG'deki model çalışmalarından örnekler

İÖG ve KG'de deney çalışmaları bittikten sonra, İMG'de ise model çalışmaları tamamlandıktan sonra FKDT son test olarak gruplara tekrar uygulanmiştır.

\section{Bulgular}

Araştırmanın bulguları iki başlık altında sunulmuştur. ilk kısımda ön testte ve son testte verilen cevapların istatistiksel olarak karşılaştırılması 
yapılmıştır. İkinci kısımda ise kavram yanılgıları örneklerle birlikte sergilenmiştir.

\section{Birinci Alt Problemle İlgili Elde Edilen Bulgular}

Tüm gruplarda örneklem 30'dan az olduğu için FKDT'den elde edilen verilerin normal dağılıma uygunluğu Shapiro-Wilk normallik testi ile incelenmiştir. Tablo 1'de Shapiro-Wilk testi sonuçları verilmiştir.

Tablo 1. Shapiro-Wilk testi sonuçları

\begin{tabular}{lcccc}
\hline FKDT & Gruplar & İstatistik & sd & p \\
\hline Ön Uygulama & ÏÖG &, 612 & 24 &, 00 \\
& IMG &, 767 & 24 &, 00 \\
& KG &, 643 & 23 &, 00 \\
\hline Son Uygulama & ÏÖG &, 663 & 24 &, 00 \\
& IMG &, 763 & 24 &, 00 \\
& KG &, 811 & 23 &, 00 \\
\hline
\end{tabular}

Tablo 1'e göre FKBT'nin ön ve son uygulamasında verilerin normal dağılım göstermediği [İÖGön-son ( $p=0,00 ; p<, 05)$, İMGön-son $(p=0,00 ; p<, 05)$ KGön-son $(p=0,00 ; p<, 05)]$ görülmektedir. Bu nedenle anlamlılık analizlerinde nonparametrik testler tercih edilmiştir.

Tablo 2' de ön testte gruplar arasında anlamlı bir fark olup olmadığının belirlenmesi amaciyla yapılan Kruskall-Wallis testi sonuçları verilmiştir.

Tablo 2. Ön test verilerinin Kruskall-Wallis Testi Sonuçları

\begin{tabular}{lccccc}
\hline Gruplar & n & Sira Ortalamasi & sd & $\mathbf{X}^{\mathbf{2}}$ & p \\
\hline İÖG & 24 & 40,50 & 2 & 2,898 &, 24 \\
İG & 24 & 35,96 & & & \\
KG & 23 & 31,35 & & & \\
\hline
\end{tabular}

Tablo 2'ye göre ön testte gruplar arasında istatistiksel olarak anlamlı bir fark ortaya çıkmamıştır $\left(X^{2}=2,898, p>0,05\right)$.

Son testte gruplar arasında anlamlı bir fark olup olmadığının belirlenmesi amaciyla yapılan Kruskall-Wallis testi sonuçları Tablo 3'te verilmiştir. 
Tablo 3. Son test verilerinin Kruskall-Wallis testi sonuçları

\begin{tabular}{lccccc}
\hline Gruplar & n & S1ra Ortalamas1 & sd & $\mathbf{X}^{2}$ & p \\
\hline İÖG & 24 & 39,69 & 2 & 14,771 &, 00 \\
İMG & 24 & 43,79 & & & \\
KG & 23 & 24,02 & & & \\
\hline
\end{tabular}

Tablo 3'e göre son testte gruplar arasında istatistiksel olarak anlamlı bir fark tespit edilmiştir $\left(\mathrm{X}^{2}=14,771, \mathrm{p}<, 05\right)$. Anlamlı farkın hangi gruplar arasında olduğunu ortaya çıkarmak amacıyla Mann-Whitney U testi yapılmıştır. Tablo 4'te Mann-Whitney U testi sonuçları verilmiştir.

Tablo 4. Son Test Verilerinin Mann-Whitney U Testi Sonuçları

\begin{tabular}{lccccc}
\hline Gruplar & $\mathbf{n}$ & Sira Ortalamasi & S1ralar Toplami & U & p \\
\hline IÖG & 24 & 23,04 & 553,00 & 253 &, 392 \\
IMG & 24 & 25,96 & 623,00 & & \\
\hline ÏÖG & 24 & 29,15 & 699,50 & 152 &, 004 \\
KG & 23 & 18,63 & 428,50 & & \\
\hline IMG & 24 & 30,33 & 728,00 & 124 &, 001 \\
KG & 23 & 17,39 & 400,00 & & \\
\hline
\end{tabular}

Tablo 4'e göre son testte İÖG ve KG arasında İÖG lehine; İMG ve KG arasında ise IMG lehine anlamlı bir fark görülmüştür ( $p<, 05)$. Araştırma gruplarının son teste soru bazında verdikleri doğru cevap oranları Şekil 3'te verilmiştir.

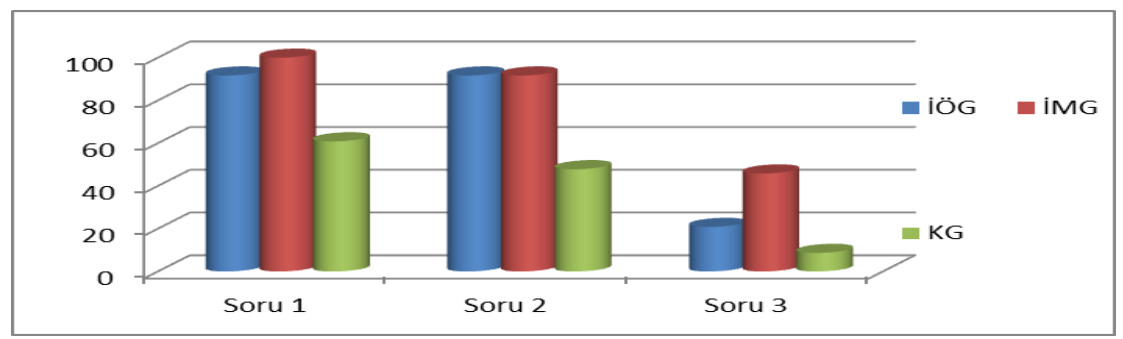

Şekil 3. Son testte grupların doğru çizim yüzdelerinin soru bazında karşılaştırılması

Şekil 3'e göre, birinci ve üçüncü soruda en yüksek ortalamayı İMG yaparken, ikinci soruda İMG ve İÖG'nin ortalamalarının eşit olduğu görülmektedir. Ayrıca, birinci ve ikinci soruya doğru cevap oranının yüksek olduğu, üçüncü soruda ise öğretmen adaylarının zorlandıkları görülmektedir. 


\section{2. İkinci Alt Probleme İlişkin Bulgular}

$\mathrm{Bu}$ kısımda FKDT'deki sorulara öğretmen adaylarının verdikleri cevaplar kavramsal olarak analiz edilmiş ve kavram yanılgılarından örnekler verilmiştir. Şekil 4'te FKDT'nin birinci sorusu verilmiştir.

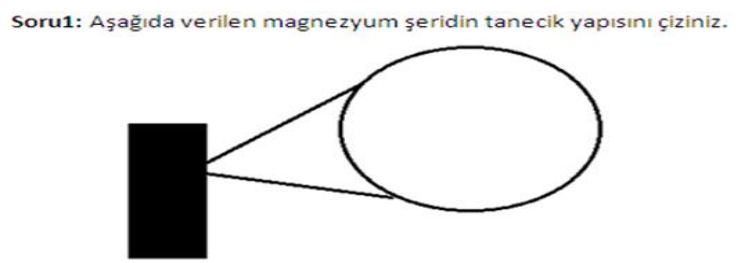

Şekil 4. FKDT'nin birinci sorusu

FKDT'nin birinci sorusunda öğretmen adaylarından magnezyum taneciklerini tek tür sembolle göstermeleri, sık ve düzenli olarak çizmeleri beklenmektedir. Birinci soru için öğretmen adaylarının ön ve son testte sahip oldukları kavram yanılgıları ve oranları Tablo 5'te verilmiştir.

Tablo 5. Birinci soru ile ilgili kavram yanılgıları ve oranları

\begin{tabular}{|c|c|c|c|c|c|c|c|}
\hline \multirow[t]{2}{*}{ Çizimler } & & \multicolumn{2}{|c|}{ İÖG \% } & \multicolumn{2}{|c|}{ İMG \% } & \multicolumn{2}{|c|}{ KG \% } \\
\hline & & Ön & Son & Ön & Son & Ön & Son \\
\hline $\begin{array}{l}\text { Doğru } \\
\text { Çizim }\end{array}$ & $\begin{array}{l}\text { Magnezyum tanecik- } \\
\text { lerinin atomik yapıda } \\
\text { sık ve düzenli bir } \\
\text { şekilde çizilmesi }\end{array}$ & 62,5 & 91,7 & 45,8 & 100 & 39,1 & 52,2 \\
\hline \multirow{8}{*}{$\begin{array}{l}\text { Hatalı } \\
\text { Çizimler }\end{array}$} & Tek tanecik çizilmesi & 4,2 & - & - & - & - & - \\
\hline & $\begin{array}{l}\text { Magnezyum tanecik- } \\
\text { lerinin moleküler } \\
\text { yapıda çizilmesi }\end{array}$ & 4,2 & - & - & - & 4,3 & 4,3 \\
\hline & $\begin{array}{l}\text { Tanecikler arasında } \\
\text { gereğinden fazla } \\
\text { boşluk bırakılması }\end{array}$ & 25 & 4,2 & 54,2 & - & 26,1 & 30,4 \\
\hline & Bütüncül çizim & - & - & - & - & 4,3 & - \\
\hline & $\begin{array}{l}\text { Taneciklerin düzenli } \\
\text { olarak çizilmemesi }\end{array}$ & 4,2 & - & 25 & - & 13 & 17,4 \\
\hline & $\begin{array}{l}\text { Elektron katman } \\
\text { modeli çizilmesi }\end{array}$ & 8,3 & - & - & - & 4,3 & - \\
\hline & $\begin{array}{l}\text { Birden fazla çeşit } \\
\text { tanecik çizilmesi }\end{array}$ & - & - & - & - & 4,3 & - \\
\hline & Cevap Yok & 4,2 & 4,2 & - & - & 21,7 & - \\
\hline
\end{tabular}

*Bazı öğretmen adaylarının çizimleri birden fazla kavram yanılgısı içerebilmektedir. 
Tablo 5'e göre doğru çizim oranının ön testte en fazla İÖG'de, son testte ise en fazla IMG'de olduğu görülmektedir. Tüm gruplarda doğru cevap oranının son testte arttığ1 görülmüştür. Kavram yanılgılarına bakıldığında ise, ön ve son testte en fazla yapılan yanılgının "tanecikler arasında gereğinden fazla boşluk bırakılması" olduğu görülmektedir. Yine, son testte en fazla kavram yanılgısının KG'de olduğu göze çarpmaktadır.

Şekil 5'te öğretmen adaylarının birinci soru ile ilgili doğru ve yanlış çizimlerinden örnekler görülmektedir.

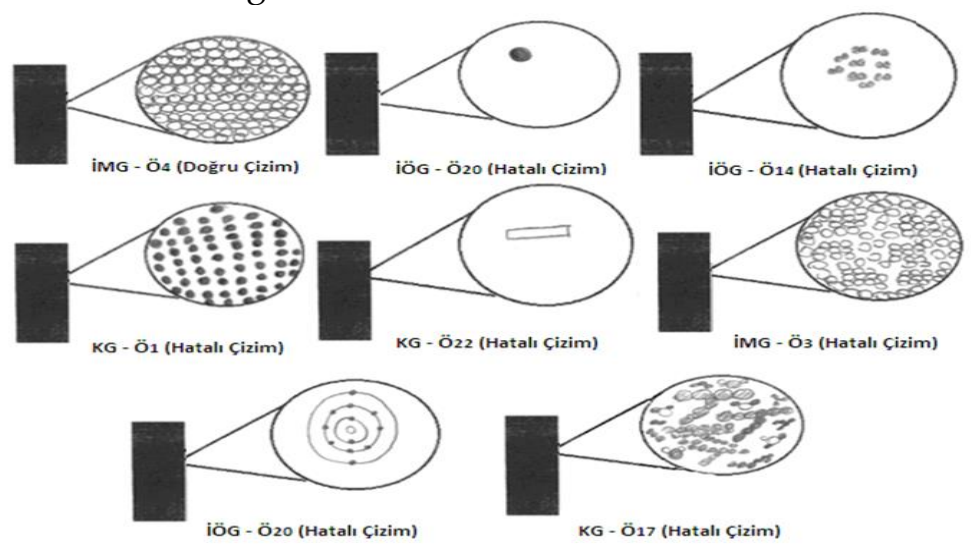

Şekil 5. Birinci soru ile ilgili doğru ve yanlış çizimlerden örnekler

Şekil 5'e bakıldığında çizimlerde, öğretmen adaylarının magnezyum atomu taneciklerini moleküler olarak göstermesi, katı maddenin tanecikleri arasında oldukça fazla boşluk çizmesi, bütüncül gösterim, elektron katman modeli çizilmesi ve aynı maddenin taneciklerinin farklı tür sembollerle gösterilmesi gibi yanılgılar görülmektedir. Şekil 6'da FKDT'nin ikinci sorusu verilmiştir.

Soru2: Verilen magnezyum şerit küçük parçalara bölünüyor. Aşağıda bu bölünen parçalardan biri verilmiştir, tanecik yapısını çiziniz.

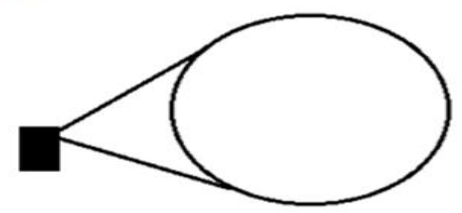

Şekil 6. FKDT'nin ikinci sorusu

FKDT'nin ikinci sorusunda, öğretmen adaylarından küçük parçalara bölünen magnezyum şeridin taneciklerini, birinci soruda çizdikleri tane- 
ciklerle aynı sembolle gösterecek şekilde, tek çeşit, sık ve düzenli olarak çizmeleri beklenmektedir. İkinci soru için öğretmen adaylarının ön ve son testte sahip oldukları kavram yanılgıları ve oranları Tablo 6'da verilmiştir.

Tablo 6'ya göre doğru çizim oranının ön testte en fazla İÖG'de, son testte ise İÖG ve İMG'de olduğu görülmektedir. Tüm gruplarda doğru cevap oranının son testte arttığı görülmüştür. Kavram yanılgılarına bakıldığında ise, ön ve son testte en fazla yapılan yanılgının "tanecikler arasinda gereğinden fazla boşluk bırakılması" olduğu görülmektedir. Yine, son testte en fazla kavram yanılgısının KG'de olduğu dikkat çekmektedir.

Tablo 6. İkinci soru ile ilgili kavram yanılgıları ve oranları

\begin{tabular}{|c|c|c|c|c|c|c|c|}
\hline \multicolumn{2}{|r|}{ Çizimler } & \multicolumn{2}{|c|}{ İÖG \% } & \multicolumn{2}{|c|}{ İMG \% } & \multicolumn{2}{|c|}{ KG \% } \\
\hline & & Ön & Son & Ön & Son & Ön & Son \\
\hline 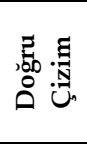 & $\begin{array}{l}\text { Taneciklerin, birinci soruda çizilen mag- } \\
\text { nezyum tanecikleri ile aynı modelde, } \\
\text { atomik yapıda, sık ve düzenli bir şekilde } \\
\text { çizilmesi }\end{array}$ & 62,5 & 91,7 & 45,8 & 91,7 & 34,8 & 47,8 \\
\hline \multirow{11}{*}{ 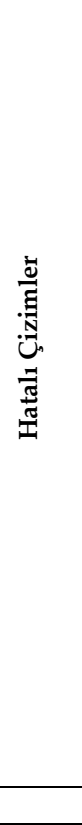 } & Tek tanecik çizilmesi & 4,2 & - & - & - & - & - \\
\hline & $\begin{array}{l}\text { Magnezyum taneciklerinin moleküler } \\
\text { yapıda çizilmesi }\end{array}$ & 4,2 & - & - & - & 4,3 & 4,3 \\
\hline & $\begin{array}{l}\text { Tanecikler arasında gereğinden fazla } \\
\text { boşluk bırakılması }\end{array}$ & 25 & 4,2 & 37,5 & 4,2 & 26,1 & 39,1 \\
\hline & Bütüncül çizim & - & - & - & - & 8,7 & - \\
\hline & Taneciklerin düzenli çizilmemesi & 8,3 & - & 20,8 & 4,2 & 21,7 & 17,4 \\
\hline & $\begin{array}{l}\text { Birinci soruda çizilen elektron katman } \\
\text { modelinin elektron sayısını yarıya indi- } \\
\text { rerek çizilmesi }\end{array}$ & 4,2 & - & - & - & 4,3 & - \\
\hline & $\begin{array}{l}\text { Birinci soruda çizilen magnezyum tane- } \\
\text { ciklerinden farklı model taneciklerin } \\
\text { çizilmesi }\end{array}$ & - & - & 4,2 & - & 8,7 & - \\
\hline & $\begin{array}{l}\text { Birinci soruda çizilen magnezyum tane- } \\
\text { ciklerinden daha büyük taneciklerin } \\
\text { çizilmesi }\end{array}$ & - & - & 4,2 & - & - & - \\
\hline & $\begin{array}{l}\text { Birinci soruda çizilen magnezyum tane- } \\
\text { ciklerinden daha küçük taneciklerin } \\
\text { çizilmesi }\end{array}$ & 4,2 & - & 4,2 & - & - & - \\
\hline & $\begin{array}{l}\text { Birinci soruda çizilen magnezyum tane- } \\
\text { ciklerinden daha düzensiz taneciklerin } \\
\text { çizilmesi }\end{array}$ & - & - & 4,2 & - & - & - \\
\hline & Cevap Yok & 8,3 & 4,2 & - & - & 21,7 & - \\
\hline
\end{tabular}

*Bazı öğretmen adaylarının çizimleri birden fazla kavram yanılgısı içerebilmektedir. 
Şekil 7'de öğretmen adaylarının ikinci soru ile ilgili doğru ve yanlış çizimlerinden örnekler görülmektedir.

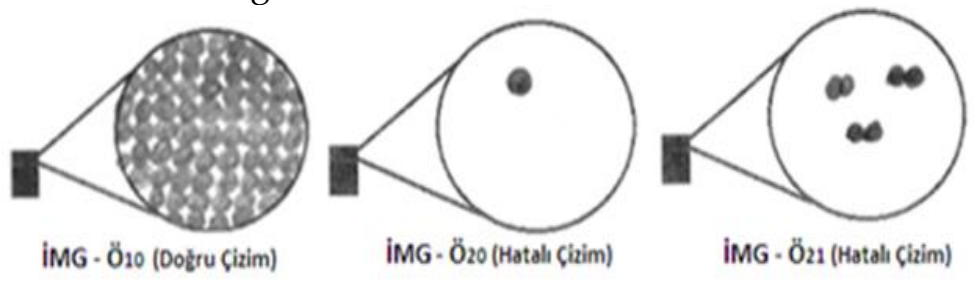

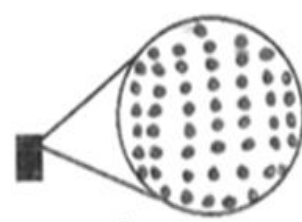

KG - Ö1 (Hatalı çizim)

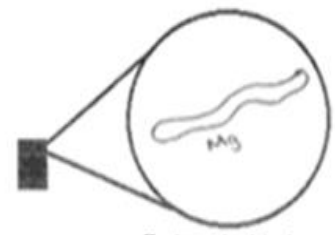

KG · Ö7 (Matal Şizim)

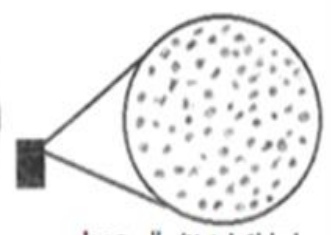

iMG - 0̆7 (Hatal çizim)

Şekil 7. İkinci soru ile ilgili doğru ve yanlış çizimlerden örnekler

Şekil 7'ye bakıldığında çizimlerde, öğretmen adaylarının tek tanecik çizmesi, magnezyum atomu taneciklerini moleküler olarak göstermesi, katı maddenin tanecikleri arasında oldukça fazla boşluk çizmesi ve bütüncül gösterim gibi yanılgılar görülmektedir.

Şekil 8'de bazı öğretmen adaylarının ön testte ilk soruda yaptıkları yanlış çizimler ile ikinci soruda yaptıkları yanlış çizimler karşılaştırmalı olarak verilmiştir.

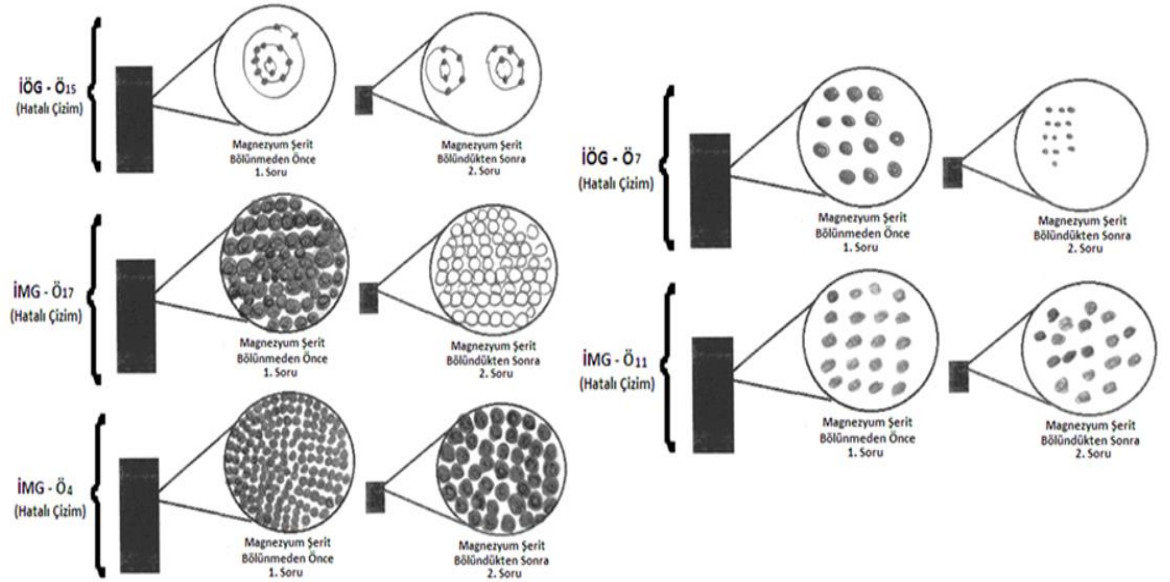

Şekil 8. Ön testte birinci ve ikinci soruda yapılan yanlış çizimlerden örnekler 
Şekil 8'e göre tanecikli yapıyı gösterirken elektron katman modelini kullanan öğretmen adayının her iki soruya da benzer çizim yaptığı, bazı öğretmen adaylarının aynı maddenin fiziksel değişim geçirmesinden sonra tanecikli gösterimini yaparken farklı büyüklük ve gösterimde sembollerle çizim yaptı̆̆ ve madde bölündügünde taneciklerin de küçüleceğini düşünen öğretmen adaylarının olduğu görülmektedir. Şekil 9'da FKDT'nin üçüncü sorusu verilmiştir.

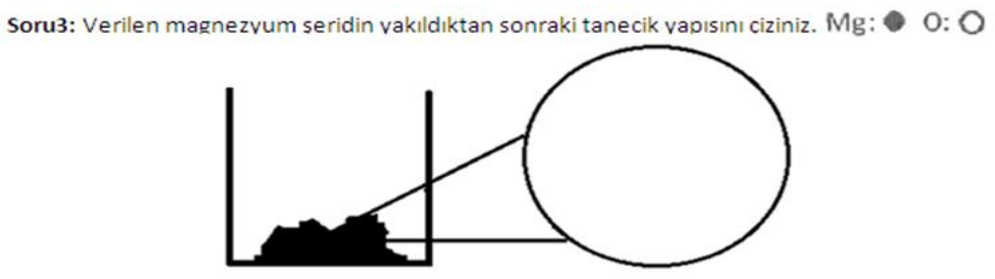

Şekil 9. FKDT'nin üçüncü sorusu

FKDT'nin üçüncü sorusunda öğretmen adaylarına magnezyum ve oksijenin tanecik sembolü verilmiş ve magnezyum şerit yandıktan sonra oluşan maddenin tanecik modelini çizmeleri istenmiştir. Öğretmen adaylarından magnezyum ve oksijenin tanecik sembollerini uygun sayıda ve şekilde birleştirerek, yanma olayından sonra oluşan $\mathrm{MgO}$ katısının taneciklerini tek çeşit, sık ve düzenli olacak şekilde çizmeleri beklenmektedir. Üçüncü soru için öğretmen adaylarının ön ve son testte sahip oldukları kavram yanılgıları ve oranları Tablo 7'de verilmiştir.

Tablo 7. Üçüncü soru ile ilgili kavram yanılgıları ve oranları

\begin{tabular}{|c|c|c|c|c|c|c|c|}
\hline \multirow[t]{2}{*}{ Çizimler } & & \multicolumn{2}{|c|}{ İÖG \% } & \multicolumn{2}{|c|}{ İMG \% } & \multicolumn{2}{|c|}{ KG \% } \\
\hline & & Ön & Son & Ön & Son & Ön & Son \\
\hline \multirow[t]{3}{*}{$\begin{array}{l}\text { Doğru } \\
\text { Çizim }\end{array}$} & $\begin{array}{l}\text { Magnezyum oksit molekülle- } \\
\text { rinin sık ve düzenli bir şekilde } \\
\text { çizilmesi }\end{array}$ & - & 20,8 & 8,3 & 45,8 & - & 8,7 \\
\hline & $\begin{array}{l}\text { Magnezyum oksit molekülleri } \\
\text { arasında fazla boşluk bırakıl- } \\
\text { ması }\end{array}$ & 41,7 & 12,5 & 16,7 & 12,5 & 17,4 & 21,7 \\
\hline & $\begin{array}{l}\text { Magnezyum oksit molekülleri } \\
\text { arasında hiç boşluk bırakıl- } \\
\text { maması }\end{array}$ & 12,5 & - & 8,3 & - & - & - \\
\hline Hatalı & Reaksiyona girmeyen magnez- & - & - & - & - & 4,3 & - \\
\hline
\end{tabular}




\begin{tabular}{|c|c|c|c|c|c|c|c|}
\hline \multirow[t]{7}{*}{ Çizimler } & \multicolumn{7}{|l|}{ yum atomlarının çizilmesi } \\
\hline & $\begin{array}{l}\text { Reaksiyona girmeyen oksijen } \\
\text { atomlarının çizilmesi }\end{array}$ & - & - & - & - & 4,3 & - \\
\hline & Bütüncül çizim & 4,2 & - & - & - & 4,3 & - \\
\hline & $\begin{array}{l}\text { Magnezyum oksit molekülle- } \\
\text { rinin düzenli çizilmemesi }\end{array}$ & - & - & 16,7 & 12,5 & 8,7 & 13 \\
\hline & Ürün oluşturulmaması & - & - & 54,2 & 12,5 & 30,4 & 34,8 \\
\hline & Yanlış ürün oluşturulması & 54,2 & 25 & 12,5 & 8,3 & 30,4 & 21,7 \\
\hline & Cevap Yok & 12,5 & 41,7 & 4,2 & 8,3 & 21,7 & 4,3 \\
\hline
\end{tabular}

*Bazı öğretmen adaylarının çizimleri birden fazla kavram yanılgısı içerebilmektedir.

Tablo 7'ye göre doğru çizim oranının ön testte en fazla ÏÖG'de, son testte ise en fazla İMG'de olduğu görülmektedir. Tüm gruplarda ön ve son testte doğru cevap oranının düşük olduğu görülmüştür. Kavram yanılgılarına bakıldığında ise, ön testte en fazla yapılan yanılgının "yanlış ürün oluşturulması", son testte ise "ürün oluşturulmaması" olduğu görülmektedir. Yine, son testte en fazla kavram yanılgısının $K^{\prime}$ 'de olduğu göze çarpmaktadır.

Şekil 10'da öğretmen adaylarının üçüncü soru ile ilgili doğru ve yanlış çizimlerinden örnekler görülmektedir.

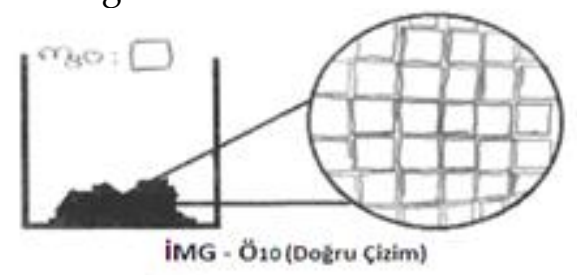

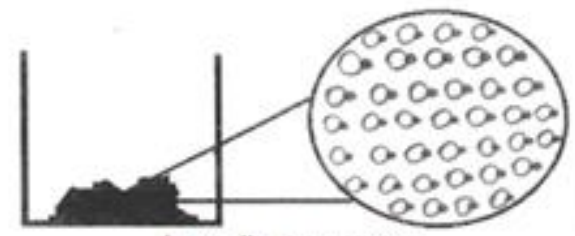

imG - Ö1 (Hatah çizim)

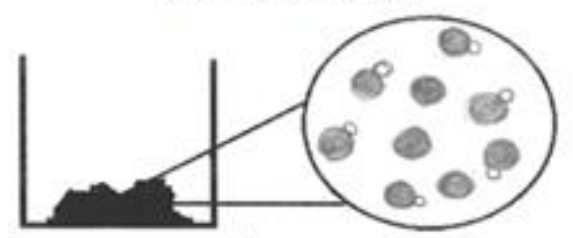

KG - Ös (Hatah çizim)

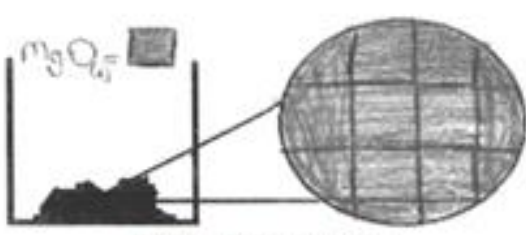

iMG - Ö2 (Hatalı çizim)

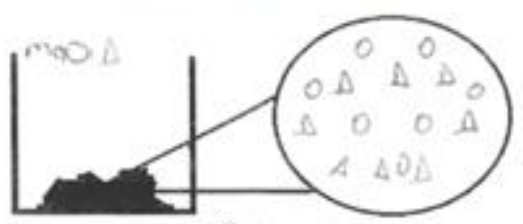

KG - Ö10 (Hatalı Cizim) 


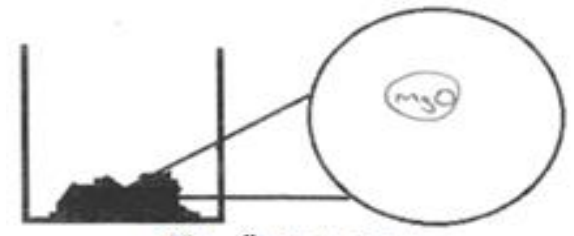

IÖG - Ö1 (Hatah çizim)

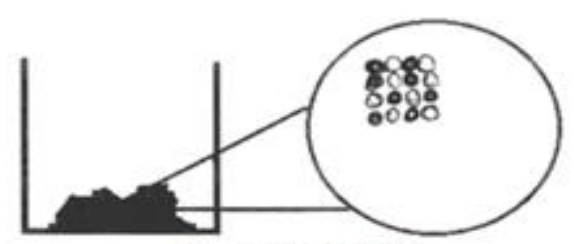

KG - Ö21(Hatalı çizim)

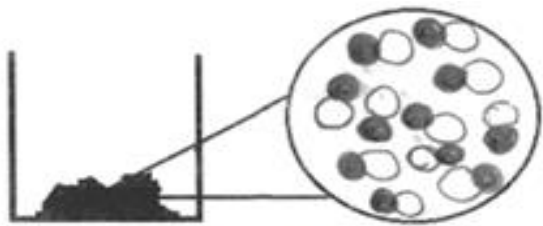

iMG - Ö7 (Hatalt çizim)

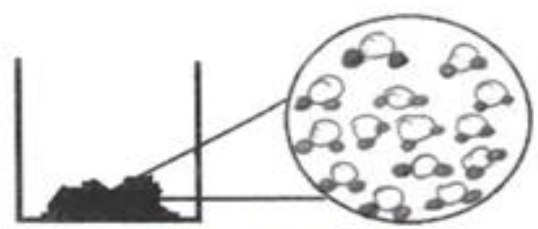

iMG - Ö.12(Hatalı Çizim)

Şekil 10. Üçüncü soru ile ilgili doğru ve yanlış çizimlerden örnekler

Şekil 10'a bakıldığında çizimlerde, öğretmen adaylarının katı maddenin tanecikleri arasında oldukça fazla boşluk çizmesi, bütüncül gösterim, yanlış ürün oluşturma ve ürün oluşturmama gibi yanılgılar görülmektedir.

\section{Tartışma ve Sonuç}

Araştırmada FKDT'nin ön test verilerine göre gruplar arasında anlamlı bir farkl11ı belirlenmemiştir ( $>00,05)$. Buna göre uygulamaya geçilmeden önce öğretmen adaylarının fiziksel ve kimyasal değişimler konusundaki ön bilgilerinin denk olduğu söylenebilir. Bu durum, öğretmen adaylarının okudukları bölüme çoğunlukla benzer puanlarla girmiş olmalarından dolayı sahip oldukları başarı düzeyinin birbirlerine yakın olmasından kaynaklanmış olabilir.

FKDT'nin son test olarak uygulamasinda ise gruplar arasında anlamlı bir farklılık olduğu tespit edilmiştir $(p<0,05)$. Buna göre konunun kavranmasında en başarılı grubun İMG olduğu, İÖG'nin de KG'ye göre başarılı olduğu tespit edilmiştir. Buradan hareketle işbirlikli öğrenme ile desteklenen modellerin fiziksel ve kimyasal değişim konusunun anlaşılmasında etkili olduğu söylenebilir. İşbirlikli öğrenme destekli modellerin kimya kavramlarının anlaşılmasında etkili olduğu Çavdar ve Doymuş (2016b, 2018), Çavdar vd. (2016), Doymuş vd. (2010), Karaçöp ve 
Doymuş (2013), Okumuş ve Doymuş $(2017,2018)$ ve Warfa, Roehring, Schneider ve Nyacwaya (2014) çalışmalarında da belirlenmiştir. Bu sonuçların ortaya çımasında, modellerin duyu organları ile hissedilemeyen soyut kavramları somutlaştırılarak görerek ve dokunarak deneyimleme fırsatı sunmasının etkili olduğu düşünülmektedir (Cheng ve Lin, 2015; Develaki, 2017; Kimberlin ve Yezierski, 2016; Krell vd., 2015; Wang vd., 2014). Modellerin kimyada kavramsal anlamayı kolaylaştırdığı Develaki (2017), Kimberlin ve Yezierski (2016), Krell vd. (2015), Oliva vd. (2015), Prins, Bulte ve Pilot (2016) ve Wang vd. (2014) çalışmalarında da belirlenmiştir. Ayrıca, IÖG'nin KG'ye göre fiziksel ve kimyasal değişim konusunun anlaşılmasında daha başarılı olduğu belirlenmiştir. İşbirlikli öğrenmenin kimya konularında kavramsal anlamayı artırdığı Acar ve Tarhan (2008), Belge Can ve Boz (2016), Çavdar ve Doymuş (2016b, 2018), Eymur ve Geban (2017) Karaçöp ve Doymuş (2013) ve Okumuş ve Doymuş'un (2018) çalışmalarında rapor edilmiştir. Bu araştırmada da konuyla ilgili kavramsal anlamaların sağlanmasında işbirlikli ÖTBB yönteminin etkili olduğu görülmüştür. Bu durumun ortaya çıkmasında, ÖTBB'nin etkisinin olduğu düşünülmektedir. Çünkü ÖTBB yönteminde öğretmen adayları hem grupça çalışma firsatı bulmuş hem de araştırmacı konuyu genel hatları ile anlatmıştır. Ayrıca, öğretmen adayları grup çalışması sırasında yüz yüze iletişim sağlayarak birlikte çalışmışlar ve kendilerinin ve grup arkadaşlarının öğrenmelerinin sorumluluğunu almışlardır. ÖTBB'nin etkili bir işbirlikli öğrenme yöntemi olduğu literatürde de ifade edilmiştir (Okumuş vd. 2017). Tüm bu sonuçların ışığında kimya konularının tanecik boyutunda anlaşılmasının sağlanmasında işbirlikli öğrenmenin ÖTBB yönteminin ve modellerin birlikte kullanılması önerilmektedir.

Araştırmada elde edilen kavram yanılgılarına bakıldığında ise "katı taneciklerin çiziminde tanecikler arası mesafenin fazla gösterilmesi" yanılgısına tüm sorularda rastlanılmıştır. Bu durum, öğretmen adaylarının çizimlerine dikkat etmemelerinden kaynaklanabilir. Çünkü birçoğu katıların taneciklerin sık ve düzenli dizildiğini bilmektedir. Bu konuda uygulamalar sırasında öğretmen adaylarının çizimlerini yaparken nelere dikkat etmeleri gerektiği konusunda bilgilendirilmelerinin yeterli olmadığı söylenebilir. Bu yanılg1 Smith ve Villarreal (2015) ve Vikström (2014) araştırmalarında da rapor edilmiştir. Bir diğer önemli yanılgı ise maddeyi 
bütüncül düşünme yanılgısıdır. Maddenin tanecikli yapıda değil de bütüncül olarak algılanması yanılgısı Çavdar ve Doymuş (2018), Demircioğlu vd (2012), Jaber ve Boujaoude (2012) ve Okumuş ve Doymuş (2018) araştırmalarında da belirlenmiştir. Bu durum, öğretmen adaylarının maddeyi zihinlerinde tanecikli olarak canlandıramamalarından kaynaklanmış olabilir. Diğer taraftan bunun nedeni öğrencilerin ön öğrenmelerindeki yanlış anlamalar da olabilir. Çünkü bir kavramı ilk defa öğrenmek kavram yanılgılı anlamayı düzletmekten daha kolaydır. Öğretmen adaylarının ortaokul ve lise seviyesinde maddenin tanecikli yapısı konusunda kavram yanılgılarına sahip olmaları, lisans seviyesinde de bu yanılgılarını sürdürmelerine neden olmuş olabilir. Bu bakımdan özellikle ortaokul seviyesinde kavramların doğru öğrenilmesi sonraki öğrenim seviyelerini de olumlu etkileyecektir. Araştırmada belirlenen bir diğer önemli yanılg1, "fiziksel değişime uğrayan maddenin taneciklerinin de değişeceği" düşüncesidir. Bu durum, fiziksel değişim ve kimyasal değişim olaylarının tam olarak anlaşılamamasından kaynaklanmaktadır. Buna göre öğretmen adayları fiziksel değişimi tanecik boyutunda düşünememekte, makro özellikleri mikro özelliklere atfetmektedir. Benzer yanılgı Okumuş ve Doymuş (2017) çalışmalarında da tespit edilmiştir. Fiziksel ve kimyasal değişimin birbirinden ayırt edilememesi Ayvacı ve Şenel Çoruhlu (2009), Eilks vd. (2007) ve Kıngır ve Geban (2014) araştırmalarında da raporlanmıştır. Fiziksel ve kimyasal değişim olayları ile ilgili çeşitli kavram yanılgılarının olduğu yine literatürde ifade edilmektedir (Chang vd., 2014; Cheng ve Gilbert, 2017; Çayan ve Karsl1, 2015; Jaber ve Boujaoude, 2012; Kingir ve Geban, 2014; Yan ve Talanquer, 2015).

Bazı öğretmen adaylarının uygulamadan önce konuyla ilgili sahip oldukları kavram yanılgılarını uygulamadan sonra da devam ettirdikleri görülmüştür. Birçok araştırmada kavram yanılgılarının kolay kolay ortadan kaldırılamadığı ifade edilmektedir (Adadan, 2014; Çavdar ve Doymuş, 2016b, 2018; Çavdar vd., 2016; Okumuş ve Doymuş, 2017; Tsai, 1999). Bu durum zihne yerleşmiş yanılgıların değiştirilmesinin kolay olmadığını göstermektedir. Kavram yanılgılarının tam olarak ortadan kaldırılması için daha uzun süreli çalışmalara gerek olduğu düşünülmektedir. Diğer taraftan öğrenciyi sürece aktif katan farklı yöntem ve tekniklerle birlikte farklı görsel materyallerin de denenip etkisine bakılabilir. 


\title{
EXTENDED ABSTRACT
}

\section{Effect of Cooperative Learning and Models on the Understanding of Particulate Structure of Physical and Chemical Changes}

\author{
* \\ Oylum Çavdar* - Seda Okumuş** - Mustafa Alyar*** Kemal Doymuş** \\ ${ }^{*}$ Muş Alparslan University, ${ }^{* *}$ Atatürk University, ${ }^{* * *}$ Çukurova University
}

The subject of physical and chemical changes is difficult to understand in micro level and students have various misconceptions (Demircioğlu et al., 2012; Lee et al., 1993; Karslı and Ayas, 2013; Kingır and Geban, 2014; Smith and Nakleh, 2011). The use of active learning methods can be effective in terms of providing conceptual understanding and eliminating misconceptions. Cooperative learning from active learning methods is an effective method for students' academic achievement and conceptual understanding (Belge Can and Boz, 2016; Doymuş et al., 2010 Eymur and Geban, 2017; Karaçöp and Doymuş, 2013). In addition, it is stated in the literature that models are an effective material in concreting abstract situations (Adadan, 2014; Çavdar and Doymuş 2016b, 2018; Jaber and Boujaoude, 2012; Krell et al., 2015; Okumuş and Doymuş, 2017; Oliva et al., 2015). In this respect, cooperative learning and models will be used to understand physical and chemical changes in this research.

The aim of this study is to determine the effectiveness of cooperative learning and models on chemical and physical change topic as particulate nature of matter level.

\section{Method}

Quasi-experimental method with pre and posttest was used in research. Research sample is consisted 71 prospective science teachers (PST). Three research groups were in this study (CLG: cooperative learning group, 
$\mathrm{n}=24$; CLMG: cooperative learning and model group, $\mathrm{n}=24$; and control group, $\mathrm{CG}, \mathrm{n}=23$ ).

For collecting data, the Physical and Chemical Changing Test (PCCT) consisting of three open-ended questions. It was asked to drawing of the magnesium strip of the particle structure in the first question, to drawing of the particles of a small part divided from this strip in the second question, to drawing of the particles of this strip when it was burned in the third question. The pre-and post- test was used.

Primarily in the research, the PSTs studied in general chemistry laboratory-I course at first class were divided into three groups (CLMG, CLG, CG) and then the PCCT was implemented to the PSTs in these groups as pre-test. After, the physical and chemical changes experiment was conducted by the PSTs in the each group according to their method.

The PSTs have observed changes by dividing into small pieces the magnesium strips with the scissors in the first part of the physical and chemical changes experiment. In the second part of the experiment, the PSTs have burned the magnesium strips on spirit stove and examined the products have gained in the crucible.

According to STAD method applied in CLG, the PSTs were divided into teams in which they will study cooperatively. Primarily, the researchers have taught the physical and chemical changes topic end then each team have discussed the topic with their teammates by reading the experiment sheets and conducted the physical and chemical changes experiment. In CLMG, in addition to the method in CLG, the play dough and molecular models are given to the teams after the experiment. Then, it was asked to demonstrating the evaporation of water as a physical change and formation of water as a chemical change by using molecular models and play dough at particulate level from each team. In CG, traditional laboratory approach was implemented and the PSTs were divided into groups. After, each group has conducted the physical and chemical changes experiment by reading the experiment sheets. In the end of the implementations, PCCT was implemented to the students in the all groups as post-test again.

PSTs' drawings obtained were scored as 10 point for correct drawing, 0 point for false drawing. For evaluating normality Shapiro Wilk test was used. In order to analyses data, Kruskall Wallis test and Mann-Whitney 
U test were utilized. Primarily, data were analyzed on the basis of three questions and then analyzed one by one. After, PSTs' drawings were examined in detail, the correct drawings and similar incorrect drawings were categorized and calculated their percent for each question. Thus, PSTs' misconceptions were determined, given in the table and exemplified.

\section{Findings, Discussion and Results}

There was not a statistically significant difference among groups according to Kruskall Wallis test in pre-test ( $\mathrm{p}>$.05). Hence, the prior knowledge of the groups was equal before the applications. After the applications, according to Kruskall Wallis test, a significant difference among groups were found in the post-test ( $>$ >.05). As Mann-Whitney U test, a significant difference between CLG and CG in favor of CLG and between CLMG and CG in favor of CLMG were found. Using cooperative learning and models together had positive effect on PSTs' understanding to physical and chemical changes topic. That models facilitate learning determined also Adadan (2014), Çavdar and Doymuş (2016b, 2018), Krell, et al. (2015), and Okumuş and Doymuş $(2017,2018)$ studies. Similarly, cooperative learning facilitate the learning was determined also in Acar and Tarhan (2008), Çavdar et al. (2016), and Karaçöp and Doymuş's (2013) studies. Besides, some PSTs thought the matter as a whole rather than a particulate structure, had a problem in the particulate drawing of solid materials, and had various misconceptions in the concepts of physical and chemical change.

\section{Kaynakça / References}

Acar, B. ve Tarhan, L. (2008). Effects of cooperative learning on students' understanding of metallic bonding. Research in Science Education, $38,401-420$.

Adadan, E. (2014). Model-tabanlı öğrenme ortamının kimya öğretmen adaylarının maddenin tanecikli yapısı kavramını ve bilimsel modellerin doğasını anlamaları üzerine etkisinin incelenmesi. Ondokuz Mayıs Üniversitesi Eğitim Fakültesi Dergisi, 33(2), 378-403. 
Aksoy, G. ve Gürbüz, F. (2012). İşbirlikli iki farklı tekniğin öğrencilerin akademik başarıları üzerine etkisi. Elektronik Sosyal Bilimler Dergisi, 11(42), 67-78.

Ayvacı, H.Ş. ve Şenel Çoruhlu, T. (2009). Fiziksel ve kimyasal değişim konularındaki kavram yanılgılarının düzeltilmesinde açıklayıcı hikâye yönteminin etkisi. Ondokuz Mayıs Üniversitesi Eğitim Fakültesi Dergisi, 28, 93-104.

Belge, C. H. ve Boz, Y. (2016). Structuring cooperative learning for motivation and conceptual change in the concepts of mixtures. International Journal of Science and Mathematics Education, 14, 35-657.

Büyüköztürk, Ş., Kılıç Çakmak, E., Akgün, Ö.E., Karadeniz, Ş. ve Demirel, F. (2012). Bilimsel araştırma yöntemleri. (Geliştirilmiş 13. baskı). Ankara: Pegem Akademi Yayıncllık.

Chang, H.Y., Quintana, C. ve Krajcik, J.S. (2010). The impact of designing and evaluating molecular animations on how well middle school students understand the particulate nature of matter. Science Education, 94, 73-94.

Cheng, M.M.W. ve Gilbert, J.K. (2017) Modelling students' visualisation of chemical reaction, International Journal of Science Education, 39(9), 1173-1193.

Cheng, M.F. ve Lin, J.L. (2015). Investigating the relationship between students" views of scientific models and their development of models. International Journal of Science Education, 37(15), 24532475.

Çavdar, O. ve Doymuş, K. (2016a). İyi bir eğitim ortamı için yedi ilkenin işbirlikli öğrenme yöntemi ile kullanılmasının fen ve teknoloji dersinde başarıya etkisi. Atatürk Üniversitesi Sosyal Bilimler Enstitüsü Dergisi, 20(2), 441-466.

Çavdar, O. ve Doymuş, K. (2016b). Fen ve teknoloji dersinde işbirlikli öğrenme yönteminin iyi bir eğitim ortamı için yedi ilke ve modellerle kullanılması. Eğitimde Kuram ve Uygulama, 12(3), 741-768.

Çavdar, O. ve Doymuş, K. (2018). Karışımlar konusunun öğretilmesinde işbirlikli öğrenme yönteminin iyi bir eğitim ortamı için yedi ilke ve modellerle kullanılması. Eğitimde Kuram ve Uygulama, 14(3), 325-346. 
Çavdar, O., Okumuş, S. ve Doymuş, K. (2016). Fen eğitimi öğrencilerinin maddenin tanecikli yapısıyla ilgili anlamalarının belirlenmesi. Mustafa Kemal Üniversitesi Sosyal Bilimler Enstitüsü Dergisi, 13(33), 69-93.

Çavdar, O., Okumuş, S., Alyar, M. ve Doymuş, K. (2016). Maddenin tanecikli yapısının anlaşılmasına farklı yöntemlerin ve modellerin etkisi. Erzincan Ĕ̆itim Fakültesi Dergisi, 18(1), 555-592.

Çayan, Y. ve Karslı, F. (2015). Fiziksel ve kimyasal değişim konusundaki kavram yanılgılarının giderilmesinde probleme dayalı öğrenme yaklaşımının etkisi. Kastamonu Eğitim Fakültesi Dergisi, 23(4), 1437-1452.

Demircioğlu, H., Demircioğlu, G., Ayas, A. ve Kongur, S. (2012). Onuncu sınıf öğrencilerinin fiziksel ve kimyasal değişme kavramları ile ilgili teorik ve uygulama bilgilerinin karşılaştırılması. Türk Fen Eğitimi Dergisi, 9(1), 162-181.

Develaki, M. (2017). Using computer simulations for promoting modelbased reasoning. Epistemological and educational dimensions. Science \& Education, 26, 1001- 1027.

Doymuş, K., Karaçöp, A. ve Şimşek, Ü. (2010). Effects of jigsaw and animation techniques on students' understanding of concepts and subjects in electrochemistry. Education Tech Research Dev, 58, 671691.

Eilks, I., Moellering, J. ve Valanides, N. (2007). Seventh-grade students' understanding of chemical reactions: Reflections from an action research interview study. Eurasia Journal of Mathematics, Science $\mathcal{E}$ Technology Education, 3(4), 271-286.

Eymur, G. ve Geban, Ö. (2017). The collaboration of cooperative learning and conceptual change: enhancing the students' understanding of chemical bonding concept. Internationa Journal of Science and Mathematics Education, 15, 853-871.

Güngör, S.N. ve Özkan, M. (2011). Fen ve teknoloji öğretiminde işbirlikli öğrenme yönteminin öğrenci tutumuna etkileri üzerine bir çalışma. Uludă̆ Üniversitesi Eğitim Fakültesi Dergisi, 24(1), 47-59.

Jaber, L.Z. ve Boujaoude, S. (2012). A macro-micro-symbolic teaching to promote relational understanding of chemical reactions. International Journal of Science Education, 34(7), 973-998. 
Johnstone, A.H. (1991). Why is science difficult to learn? Things are seldom what they seem. Journal of Computer Assisted Learning, 7, 7583.

Karaçöp, A. ve Doymuş, K. (2013). Effects of jigsaw cooperative learning and animation techniques on students' understanding of chemical bonding and their conceptions of the particulate nature of matter. Journal of Science Education Technology, 22, 186-203.

Karslı, F. ve Ayas, A. (2013). Fen bilgisi öğretmen adaylarının kimya konularında sahip oldukları alternatif kavramlar. Necatibey Ĕ̆itim Fakültesi Elektronik Fen ve Matematik Ĕ̆itimi Dergisi, 7(2), 284-313.

Kimberlin, S. ve Yezierski, E. (2016). Effectiveness of inquiry-based lessons using particulate level models to develop high school students' understanding of conceptual stoichiometry. Journal of Chemical Education, 93, 1002-1009.

Koç, Y. (2014). Fen ve teknoloji öğretmenlerinin işbirlikli öğrenme modeli hakkında bilgilendirilmesi, bu modeli smafta uygulamalarn ve elde edilen sonuçların değerlendirilmesi: A $\breve{g r}$ r il örneği. Yayımlanmamış doktora tezi, Atatürk Üniversitesi Eğitim Bilimleri Enstitüsü, Erzurum.

Krell, M., Reinisch, B. ve Krüger, D. (2015). Analyzing students' understanding of models and modeling referring to the disciplines biology, chemistry, and physics. Research in Science Education, 45(3), 367-393.

Lee, O., Eichinger, D.C., Anderson, C.W., Berkheimer, G.D. ve Blakeslee, T.D. (1993). Changing middle school studentse conceptions of matter and molecules. Journal of Research in Science Teaching, 30, 249-270.

McMillan, J.H. ve Schumacher, S. (2010). Research in education: evidencebased inquiry (7. Edition). New Jersey, Pearson.

Meşeci, B., Tekin, S. ve Karamustafaoğlu, S. (2013). Maddenin tanecikli yapısıyla ilgili kavram yanılgılarının tespiti. Dicle Üniversitesi Sosyal Bilimler Enstitüsü Dergisi, 5(9), 20-40.

Okumuş, S. ve Doymuş, K. (2017). İşbirlikli öğrenme ve modellerin yedi ilkeyle birlikte uygulanmasının kavramsal anlamaya etkisi. Mustafa Kemal Üniversitesi Sosyal Bilimler Enstitüsü Dergisi, 14(39), 431457. 
Okumuş, S. ve Doymuş, K. (2018). Modellerin okuma- yazma- uygulama yöntemi ve yedi ilke ile uygulanmasının maddenin tanecikli yapısı ve yoğunluk konularının kavramsal anlaşılmasına etkisi. Abant İzzet Baysal Üniversitesi Eğitim Fakültesi Dergisi, 18(3), 16031638.

Okumuş, S., Çavdar, O., Alyar, M. ve Doymuş, K. (2017). İşbirlikli öğrenme ve modellerin kimyasal reaksiyonlar konusunun anlaş1masına etkisi. Mehmet Akif Ersoy Üniversitesi Eğitim Fakültesi Dergisi, 44, 358-381.

Oliva, J.M., Aragón, M.M. ve Cuesta, J. (2015). The competence of modelling in learning chemical change: a study with secondary school students. International Journal of Science and Mathematics Education, 13, 751-791.

Papageorgiou, G., Stamovlasis, D. Ve Johnson, P.M (2010). Primary teachers"e particle ideas and explanations of physical phenomena: Effect of an in-service training course. International Journal of Science Education, 32(5), 629-652.

Prins, G.T., Bulte, A.M.W. ve Pilot, A. (2016). An activity-based instructional framework for transforming authentic modeling practices into meaningful contexts for learning in science education. Science Education, 100, 1092-1123.

Raviolo, A. (2001). Assessing students ${ }^{\text {ee }}$ conceptual understanding of solubility equilibrium. Journal of Chemical Education, 78(5), 629631.

Smith, K.C. ve Nakhleh, M. B. (2011). University students' conceptions of bonding in melting and dissolving phenomena. Chemistry Education Research and Practice, 12(4), 398-408.

Smith, K.C. ve Villarreal, S. (2015). Using animations in identifying general chemistry students"e misconceptions and evaluating their knowledge transfer relating to particle position in physical changes. Chemical Education Research and Practice, 16, 273-282.

Talanquer, V. (2011). Macro, submicro, and symbolic: The many faces of the chemistry:Triplet. International Journal of Science Education, 33(2), 179-195. 
Tsai, C.C. (1999). Laboratory exercises help me memorize the scientific truths: A study of eighth graders' scientific epistemological views and learning laboratory activities. Science Education, 83, 654-674.

Vikström, A. (2014). What makes the difference? Teachers explore what must be taught and what must be learned in order to understand the particulate character of matter. Science Teacher Education, 25, 709-727.

Wang, Z., Chi, S., Hu, K. ve Chen, W. (2014). Chemistry teachers' knowledge and application of models. Journal of Science Education and Technology, 23, 211-226.

Warfa, A.M., Roehring, G.H., Schneider, J.L. ve Nyacwaya, J. (2014). Collaborative discourse and the modeling of solution chemistry with magnetic 3D physical models-impact and characterization. Chemical Education Research and Practice, 15, 835- 848.

Wei, S., Liu, X. ve Jia, Y. (2013). Using rasch measurement to validate the instrument of students' understanding of models in science (SUMS). International Journal of Science and Mathematics Education, 12(5), 1067-1082.

Yan, F. ve Talanquer, V. (2015). Students' ideas about how and why chemical reactions happen: Mapping the conceptual landscape, International Journal of Science Education, 37(18), 3066-3092.

\section{Kaynakça Bilgisi / Citation Information}

Çavdar, O., Okumuş, S., Alyar, M. ve Doymuş, K. (2019). İşbirlikli öğrenme ve modellerin fiziksel vekimyasal değişim olaylarının tanecikliyapıda anlaşılmasına etkisi. OPUS-Uluslararası Toplum Araştırmaları Dergisi , 11(18), 473-500. DOI: 10.26466/opus.534640 